\title{
Community response of deep-sea soft-sediment metazoan meiofauna to the Deepwater Horizon blowout and oil spill
}

\author{
Jeffrey G. Baguley ${ }^{1, *}$, Paul A. Montagna ${ }^{2}$, Cynthia Cooksey ${ }^{3}$, Jeffrey L. Hyland ${ }^{3}$, \\ Hyun Woo Bang ${ }^{1}$, Colin Morrison ${ }^{1}$, Anthony Kamikawa ${ }^{1}$, Paul Bennetts ${ }^{1}$, \\ Gregory Saiyo ${ }^{1}$, Erin Parsons ${ }^{1}$, Meredyth Herdener ${ }^{1,2}$, Morgan Ricci ${ }^{1}$ \\ ${ }^{1}$ The University of Nevada-Reno, Reno, Nevada, USA \\ ${ }^{2}$ Texas A\&M University-Corpus Christi, Corpus Christi, Texas, USA \\ ${ }^{3}$ National Oceanic and Atmospheric Administration, National Centers for Coastal Ocean Science, Charleston, \\ South Carolina, USA
}

\begin{abstract}
The Deepwater Horizon (DWH) blowout and oil spill of 2010 released an estimated 4.9 million barrels of oil into the Gulf of Mexico. Spill-related contaminants that sank to the seafloor pose risks to benthic fauna living within bottom substrates that are unable to avoid exposure due to their relatively sedentary existence. Metazoan meiofauna are abundant and diverse members of deep-sea soft-sediment communities and play important roles in ecosystem function. We investigated the deep-sea metazoan meiofauna community response to the DWH blowout and oil spill at 66 stations ranging from $<1 \mathrm{~km}$ to nearly $200 \mathrm{~km}$ from the Mississippi Canyon Block 252 wellhead. Metazoan meiofauna abundance, diversity, and the nematode to copepod ratio (N:C) varied significantly across impact zones. Nematode dominance increased significantly with increasing impacts, and N:C spiked near the wellhead. Conversely, major taxonomic diversity and evenness decreased in zones of greater impacts that were in closer proximity to the DWH wellhead. Copepod abundance and the abundance of minor meiofauna taxa decreased where impacts were most severe, and at these severely impacted stations the abundance of ostracods and kinorhynchs was negligible. Increasing abundance and dominance by nematodes with increasing impacts likely represent a balance between organic enrichment and toxicity. Spatial analysis of meiofauna diversity and $\mathrm{N}: \mathrm{C}$ at 66 stations increased our spatial understanding of the DWH benthic footprint and suggests expanded spatial impacts in areas previously identified as uncertain.
\end{abstract}

KEY WORDS: Meiobenthos $\cdot$ Nematoda $\cdot$ Harpacticoida $\cdot$ N:C $\cdot$ Macondo Well $\cdot$ MC252

\section{INTRODUCTION}

The Deepwater Horizon (DWH) blowout in the northern Gulf of Mexico occurred on 20 April 2010 at a water depth of $1525 \mathrm{~m}$, within the Mississippi Canyon Block 252 (MC252) oil and gas lease block, releasing an estimated 4.9 million barrels (779 million liters) of oil over the following 3 months (Lubchenco et al. 2010). While oil-budget estimates indicate that oil had been removed by cleanup operations and other natural mechanisms, or was present at the surface in oil slicks, a substantial volume of hydrocarbons was trapped and transported in persistent deep-sea plumes (Ryerson et al. 2012). Persistent deep-water oil plumes represented a non-typical oil spill scenario that resulted from combined effects of deep-water origin, highly pressurized oil and gas, and direct injection of 0.77 million gallons (2.9 mil- 
lion liters) of chemical dispersants at the wellhead, resulting in several dispersed phases (Peterson et al. 2012). Large portions of hydrocarbons could have moved into offshore and deep-water sediments via several potential pathways, e.g. sinking of oil and/or dispersed oil droplets adsorbed onto suspended particles or incorporated into copepod or other biotic fecal material. Oil may have also moved in either surface or sub-surface layers due to onshoreoffshore transport of oil-laden particles, sinking of heavier oil byproducts resulting from the burning of oil, or settling of oil-mud complexes resulting from the injection of drilling mud during top-kill operations (UAC 2010). There is also increasing data to support the hypothesis that bacterial blooms in surface or mid-water environments resulted in flocculation that may have captured suspended oil and increased oil transport rates to deep-sea benthic habitats (Valentine et al. 2014). In addition, drill cuttings, drill fluids, and other containment fluids commonly used during offshore oil-drilling operations (Neff et al. 1987, 2005) may have been released and deposited to the bottom during the blowout event.

Contaminants that sink to the seafloor pose risks to benthic fauna living within or in close association with bottom substrates and unable to avoid exposure due to their relatively sedentary existence. Potential biodiversity losses are of concern because these fauna serve vital functional roles in deep-sea ecosystems, including sediment bioturbation and stabilization, organic matter decomposition and nutrient regeneration, and secondary production and energy flow to higher trophic levels (Tenore 1977, Gray 1981, Gage 2003, Thistle 2003, Danovaro et al. 2008). The deep-sea benthos represents an important source of marine biodiversity (e.g. Hessler \& Sanders 1967, Jumars 1976, Gage 1979, Hecker \& Paul 1979, Rex 1981, Rowe et al. 1982, Grassle \& Morse-Porteous 1987, Grassle \& Maciolek 1992, Blake \& Grassle 1994). High benthic species diversity has been reported for the Gulf of Mexico, with maximum diversity seen on the mid to upper continental slope at depths between 1200 and $1600 \mathrm{~m}$ (Tyler 2003, Baguley et al. 2006b, Haedrich et al. 2008, Rowe \& Kennicutt 2009, Wei et al. 2010b), which coincides with depths of the DWH well site and potential zone of exposure. The loss of benthic biodiversity can lead to severe ecological consequences, such as an exponential decline in deep-sea ecosystem functioning (Danovaro et al. 2008).

Metazoan meiofauna are ubiquitous in deep-sea soft sediments, with high abundance, biomass, and diversity (Coull 1972, Thistle 1978, Baguley et al. 2006a,b, 2008, Wei et al. 2010a). Meiofauna live on smaller spatial and temporal scales (Bell 1980, Schwinghamer 1981) and have shorter generation times and higher metabolic rates (Mahaut et al. 1995) compared to the larger macrobenthos, and lack planktonic larval dispersal (Giere 2009). These lifehistory characteristics make meiobenthos useful for studying ecological and evolutionary mechanisms (Thistle 2003), but also aid in assessing environmental or ecotoxicological effects (Montagna \& Harper 1996, Bejarano et al. 2006).

Meiofauna are known to respond to hydrocarbon pollution (Boucher 1980, Viega et al. 2010) and drilling-related environmental impacts (Montagna \& Harper 1996). Mesocosm studies and exposure assays have also provided important information about meiofauna community and species-specific responses to hydrocarbon exposure. A recent mesocosm study found significant changes in meiofauna community structure after exposure to polycyclic aromatic hydrocarbon (PAH) concentrations of 1300 and $13000 \mu \mathrm{gg}^{-1}$ (ppb) at 30- and 60-d time points (Lindgren et al. 2012). Other experimental exposure assays suggest that $\mathrm{PAH}$ exposure negatively affects the estuarine harpacticoid species Amphiascus tenuiremis, with reduced fertilization success, brood extrusion, and naupliar development (Bejarano et al. 2006). Additionally, the PAH benzo(a)pyrene is known to cause developmental delay and deformity in the harpacticoid species Tigriopus japonicus (Bang et al. 2009). However, within the metazoan meiofauna community, major taxonomic groups have not always displayed consistent responses after oil spill and contamination events (Giere 1979, Boucher 1980, Danovaro et al. 1995). Despite this variation, nematodes are thought to be more tolerant of oilrelated impacts compared to other taxa (Giere 1979). Conversely, harpacticoid copepods are generally more sensitive to pollution and environmental perturbation compared to other meiofaunal taxa, although some harpacticoid genera or families may show tolerance (Carman \& Todaro 1996). Therefore, it is reasonable to hypothesize that DWH-derived oil and gas pollution impacted deepsea meiofauna community structure and function, and that major meiofaunal taxa may have responded differently to these impacts.

Despite the extensive deep-water oil plume, most DWH investigations have focused on estuarine and coastal impacts at water depths less than $1000 \mathrm{~m}$ (Peterson et al. 2012). These estuarine and shallow- 
water coastal investigations have documented impacts to salt marshes and associated communities (McCall \& Pennings 2012, Silliman et al. 2012), and benthic microbial and eukaryote communities (Kostka et al. 2011, Bik et al. 2012, Lu et al. 2012, Mason et al. 2012), and there has been extensive reporting of water-column microbial response to the DWH-derived hydrocarbons (Kessler et al. 2011, Valentine et al. 2014). However, few studies to date have documented deep-sea benthic impacts of the DWH oil spill (White et al. 2012, Montagna et al. 2013, Fisher et al. 2014).

The deep-sea benthic chemical and biological footprint of severe to moderate impacts from the DWH blowout and oil spill encompassed an approximate area of $172 \mathrm{~km}^{2}$ in the vicinity of the wellhead and in the southwestern trajectory of the deepwater oil plume (Montagna et al. 2013). The footprint was characterized by high PAH, barium, and total petroleum hydrocarbon chemical loads with concomitant low meiofaunal and macrofaunal diversity and an elevated nematode to copepod ratio (N:C). Although Montagna et al. (2013) used meiofauna community metrics of abundance, diversity, and $\mathrm{N}: \mathrm{C}$ to define the DWH benthic footprint, differences in community structure between impact zones was not included in that analysis. Therefore, the present study further analyzes the metazoan meiofauna community and fully describes community structure patterns across the 58 stations that were categorized with respect to the DWH benthic footprint (Montagna et al. 2013). Additionally, major taxonomic diversity and $\mathrm{N}: \mathrm{C}$ are assessed spatially in relation to the DWH wellhead at 66 total stations to test the hypothesis that additional spatial resolution will improve estimates of the actual extent of DWHderived impacts to deep-sea soft-sediment community structure.

\section{MATERIALS AND METHODS}

\section{Field and laboratory methods}

Following the permanent capping of the DWH wellhead on 15 July 2010, 2 response cruises were conducted from 16 September through 19 October 2010 and 24 September through 30 October 2010 to collect biological and chemical samples from deepsea sediments. In total, 170 stations were sampled in the northeastern Gulf of Mexico deep sea $\left(27-30^{\circ} \mathrm{N}\right.$, $\left.86-91^{\circ} \mathrm{W}\right)$. Of the 170 stations sampled during the aforementioned response cruises, 68 stations were designated as the initial priority for analysis based on distance from the DWH wellhead, observed oil in sediments during response chemical analyses, and historical relevance (Lubchenco et al. 2010, NRDA 2011). In the present study, data from 66 of the 68 priority stations (Fig. 1) located from $0.5 \mathrm{~km}$ to nearly $200 \mathrm{~km}$ from the wellhead and at water depths ranging from 76 to $2767 \mathrm{~m}$ were analyzed. Two priority stations were not included in this analysis due to sample container breakage at sea or during shipping. Stations were located along a suspected gradient of contaminant effects, where 16 of the stations were arranged in a 'bulls-eye' design. This survey design was used because transects extending in radial patterns from the source of contamination and the statistical analysis of such designs have been used successfully in prior studies (e.g. Kennicutt et al. 1996).

Sediment samples were collected using an Ocean Scientific International multicorer, which takes 12 simultaneous cores from a single deployment at each station. The cores are $10 \mathrm{~cm}$ inner diameter and $60 \mathrm{~cm}$ in length. Samples were collected in a multivariate design for each station. One core was used for benthic meiofauna, one core was used for measuring oil and other drilling-related contaminants, and one core was used for basic habitat characteristics (total organic carbon, nitrogen content, sediment grain size, and sediment water content).

Meiofaunal samples were collected by immediately subsampling with a smaller core $(5.5 \mathrm{~cm}$ inner diameter), which is consistent with core samples taken in the region during prior investigations (Baguley et al. 2006a,b, 2008). The subcores were extruded into 2 vertical sections $(0-1$ and $1-3 \mathrm{~cm})$, relaxed in the field using a $7 \% \mathrm{MgCl}_{2}$ solution and subsequently preserved in $4 \%$ buffered formalin with Rose Bengal.

In the laboratory, samples were sieved over a $45 \mu \mathrm{m}$ mesh screen to remove formalin and fine sediments. Animals were then extracted from remaining sediments by 2 iterations of isopycnic centrifugation in Ludox HS-40 (deJonge \& Bouwman 1977, Burgess 2001). Meiobenthos were then enumerated and identified to the lowest possible taxonomic level, which generally was order level or higher, using a Ward zooplankton counting wheel and Leica S8APO stereomicroscope. When stereomicroscopy was not sufficient for identification, samples were viewed using a Leica DM2500 compound light microscope equipped with differential interference contrast. Sorted and enumerated taxa were transferred to $70 \%$ ethanol/ $10 \%$ glycerin and archived in the Marine Ecosystems Analysis Laboratory at the University of Nevada. 


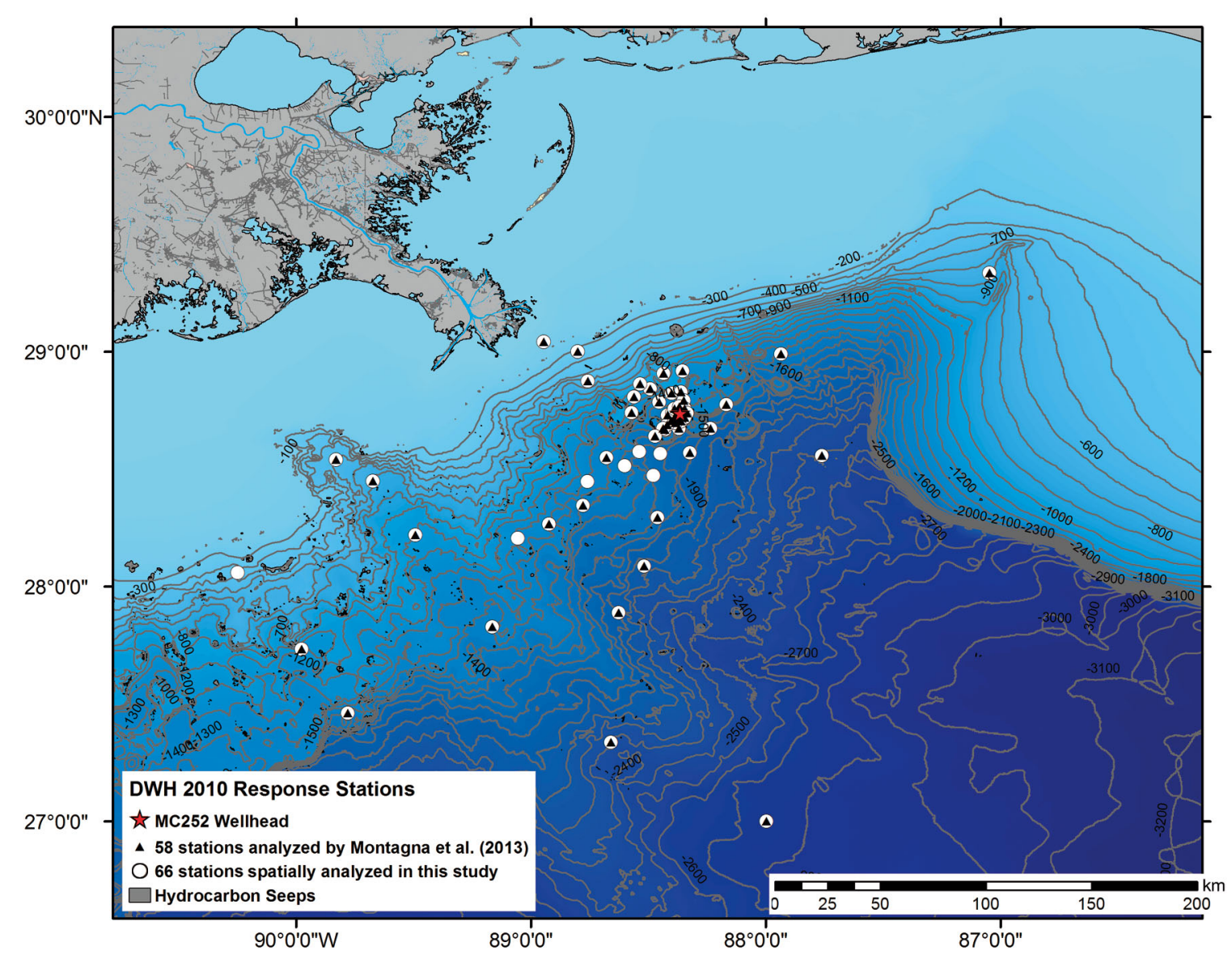

Fig. 1. Locations of the 66 priority stations relative to the Deepwater Horizon (DWH) wellhead in the northern Gulf of Mexico, and overlaid locations of 58 stations with PC1 station scores (Montagna et al. 2013) from which impact zones were defined

\section{Study design and statistical analyses}

In Montagna et al. (2013), principal components analysis (PCA) was used to classify the biological and environmental variables in a combined analysis to estimate the benthic footprint of the DWH blowout and oil spill. PCA is a variable reduction technique that can be used to reduce a large number of variables to a reduced set of new variables which are uncorrelated and contain most of the variance in the original data set. PCA was performed using the PROC FACTOR module contained in the SAS software suite. The FACTOR analysis was run using the PCA method on the correlation matrix. Further details and results of the PCA can be found in Montagna et al. (2013).

Montagna et al. (2013) plotted the PC1 station scores from 58 of 68 priority stations (Fig. 1) in ArcMap 9.3.1 to illustrate the spatial extent of DWH impacts. Jenks natural breaks optimization (goodness of variance fit) was chosen to separate
PC1 into 5 classes, because this model forms classes based on minimum within-class variance and maximum between-class variance (Jenks 1967). As such, the model successfully separated PC1 into 5 natural classes over the range of PC1 scores, where the largest positive values of PC1 represented stations with highest chemical loads and $\mathrm{N}: \mathrm{C}$, and lowest diversity indices (Hill's N1), all of which indicate DWH impacts. Conversely, the large negative PC1 scores represented high diversity and low chemical loads, indicative of natural background conditions. Intermediate PC1 scores were less than the median and are therefore not considered to be impacted by the DWH oil spill, but may represent areas of uncertain DWH impacts. While the meiofauna community metrics of total abundance, diversity, and N:C were used by Montagna et al. (2013) to construct a multivariate 'benthic footprint', the details of meiobenthic community response within the footprint were not fully described in that study. 
Here, the Jenks natural breaks classes as defined by Montagna et al. (2013) are further investigated to test the hypothesis that the meiofauna community response varied throughout the distance of the DWH deep-sea benthic footprint. The PC1 Jenks natural breaks as defined by Montagna et al. (2013) are hereafter referred to as 'impact zones' or 'zones' using the following scheme: Zone 1 = severe impacts (red), Zone 2 = moderate impacts (orange), Zone 3 = uncertain impacts (yellow), Zone $4=$ background conditions (light green), and Zone 5 = background conditions (green). Here, both 'green' zones designated as background conditions by Montagna et al. (2013) were combined into a single zone of background conditions (Zone 4) (Table 1) because meiofauna community structure was similar across all stations included in these 2 Jenks breaks.

Univariate hypothesis testing for differences in total abundance (N), major taxonomic diversity (Hill's N1), major taxonomic evenness (Pielou's $J^{\prime}$ ), and $\mathrm{N}: \mathrm{C}$ between the impact zones was accomplished with 1-way ANOVA. A 2-way ANOVA was used to test differences in community metrics between the 0-1 and 1-3 cm vertical sections of sediment and across impact zones, where the zone $\times$ section interaction term would test the null hypothesis that community metrics did not respond differently in the sediment sections in the different zones. Univariate statistical tests were carried out in the SAS statistical software package (version 9.3) using PROC GLM and Tukey's studentized range test for post hoc pairwise comparison in the 1-way ANOVA. Abundance and N:C were $\ln (x+1)$ transformed prior to analysis to meet the assumptions of the general linear model. Type III sum of squares was used in the model to account for the unbalanced design (i.e. different numbers of stations in each impact zone). Diversity and evenness indices, $\mathrm{N} 1$ and $J^{\prime}$, are already log transformations and were therefore not transformed prior to analysis. Normality was assessed with Shapiro-Wilk $W$ using the UNIVARIATE procedure, and homogeneity of variance was assessed with Levene's test during the GLM procedure. Multivariate community structure differences across impact zones were investigated using the Primer-E software suite (version 6). Data were fourth-root transformed prior to similarity analysis using the Bray-Curtis index. Station similarities were compared using non-metric multidimensional scaling (nMDS). The ANOSIM procedure was used to test for multi- variate differences in community structure across the zones. The SIMPER procedure was used to determine which taxa contributed to the similarity/dissimilarity across the DWH benthic footprint, and how these taxa contributed to the similarity/dissimilarity among the impact zones.

Montagna et al. (2013) were not able to include all 68 priority stations in their analysis due to one or more missing measurements in the multivariate dataset, limiting that analysis to 58 stations. However, meiofauna community data are available in the present study from 66 of the 68 stations. Therefore, spatial analysis of meiofauna diversity (N1) and the N:C at 66 total stations was carried using GIS software. Maps were constructed in ArcMap Geostatistical Analyst using the inverse distance weighting method for spatial interpolation. Settings were: power $=2$, up to 6 neighbors with a minimum of 4 . Interpolated surfaces were converted to vector polygon and areas calculated using the ArcMap Spatial Statistics tool.

\section{RESULTS}

In total, 380337 individuals were identified from 22 major taxonomic groups at the 66 stations. Nematoda was the dominant taxon across all samples and accounted for $86.4 \%$ of total meiofauna abundance. The next most abundant taxon was Copepoda and their nauplii, which accounted for $5.8 \%$ and $6.1 \%$ of total abundance, respectively. Polychaeta accounted for $1.1 \%$ of total abundance. Kinorhyncha and Ostracoda accounted for $0.3 \%$ and $0.2 \%$ of total abundance, respectively. The remaining $0.2 \%$ of total meiofauna abundance included representatives of the following 17 taxa: Gastrotricha, Cnidaria, Nemertea, Tardigrada, Isopoda, Tanaidacea, Cumacea, Bivalvia, Gastropoda, Acari, Turbellaria, Sipuncula, Amphipoda, Aplacophora, Loricifera, Echinodermata, and a few unidentified specimens.

Table 1. Deepwater Horizon oil spill benthic footprint impact zones derived from PC1 Jenks breaks of Montagna et al. (2013). 'Green' and 'light green' zones from Montagna et al. (2013) are combined here into a single zone of background conditions. PAH: polycyclic aromatic hydrocarbon

\begin{tabular}{|lrrrcc|}
\hline $\begin{array}{l}\text { Impact } \\
\text { zone }\end{array}$ & Description & Stn. & $\begin{array}{c}\text { Depth } \\
\text { range }(\mathrm{m})\end{array}$ & $\begin{array}{c}\text { Distance to } \\
\text { wellhead }(\mathrm{km})\end{array}$ & $\begin{array}{c}\text { PAH } \\
(\mathrm{ppb})\end{array}$ \\
\hline 1 & Severe impacts & 8 & $1508-1578$ & $0-3$ & $1162-47559$ \\
2 & Moderate impacts & 14 & $1350-1607$ & $1-60$ & $370-2436$ \\
3 & Uncertain impacts & 13 & $211-1884$ & $1-145$ & $208-1005$ \\
4 & Background conditions & 23 & $493-2767$ & $7-199$ & $28-849$ \\
\hline
\end{tabular}


Meiofauna abundance was significantly different ( $\mathrm{p}<0.0001$ ) among impact zones, and was lowest in Zone 4, which was representative of background, non-impacted conditions (Table 2). Average abundance in this zone was 1235 ind. $10 \mathrm{~cm}^{-2}$. An increasing trend in abundance was observed in Zones 3 to 1. Zone 3 had $104.1 \%$ greater abundance than background conditions and an average abundance of 2520 ind. $10 \mathrm{~cm}^{-2}$. Zone 2 had $196.5 \%$ greater abundance than background conditions and an average abundance of 3661 ind. $10 \mathrm{~cm}^{-2}$. Zone 1 had $181.4 \%$ higher abundance than background conditions and an average abundance of 3474 ind. $10 \mathrm{~cm}^{-2}$. Post hoc Tukey pair-wise comparisons revealed that Zones 1 and 2 were not significantly different from each other with respect to meiofauna abundance, but were significantly different from Zone 4 . Zone 3 was not significantly different from Zones 1, 2, or 4 .

Nematodes dominated total abundance and the average abundance pattern of this taxon by zone mirrored that of the total community. Copepod abundance was similar in Zones 2-4: $143 \pm 55$ (mean $\pm 1 \mathrm{SD}), 147 \pm 77$, and $138 \pm 117$ ind $10 \mathrm{~cm}^{-2}$, respectively. However, in Zone 1, copepod abundance was significantly lower ( $\mathrm{p}<0.0001)$, with an average abundance of $50 \pm 29$ ind. $10 \mathrm{~cm}^{-2}$. Copepod nauplii exhibited a similar pattern to adults with abundances of $23 \pm 23,138 \pm 77,157 \pm 82$, and $151 \pm 173$ ind . $10 \mathrm{~cm}^{-2}$ in Zones $1-4$, respectively. Of the minor metazoan meiofauna taxa, ostracods may also be a useful indicator of DWH impacts. Ostracod abundances were $0 \pm 1,3 \pm 2,6 \pm 3$, and $6 \pm 5$ ind. $10 \mathrm{~cm}^{-2}$ in Zones 1-4, respectively. Kinorhynch abundances were $0 \pm 1,9 \pm 26,7 \pm 5,5 \pm 9$ and ind. $10 \mathrm{~cm}^{-2}$ in Zones 1-4, respectively. Polychaete abundances were $13 \pm 12,29 \pm 37,27 \pm 21$, and $20 \pm 20$ ind. 10 $\mathrm{cm}^{-2}$ in Zones 1-4, respectively.

An inverse relationship was observed between community diversity metrics and increasing DWH impacts (Table 2). N1, $J^{\prime}$, and N:C were all significantly different among the 4 zones $(p<0.0001$ for all
3 metrics), and post hoc Tukey comparisons revealed that all zones were significantly different from one another with respect to all 3 of these metrics. Zone 4 had the greatest values of $\mathrm{N} 1$ and $J^{\prime}$, and the lowest $\mathrm{N}: \mathrm{C}$. Conversely, Zone 1 had the lowest values of N1 and $J^{\prime}$, and the greatest N:C. Hill's N1 is a measure of the effective number of dominant taxa. Here, background stations in Zone 4 have more than 2 dominant taxa, but impacted stations in Zones 1 and 2 trend toward one dominant taxon. The decreasing trend in $J^{\prime}$ with increasing DWH impacts indicates that taxa are less evenly distributed where impacts are greatest. Considering community diversity, evenness, and $\mathrm{N}: \mathrm{C}$, it is apparent that nematodes became increasingly dominant with increasing DWH impacts.

The trend toward dominance by nematodes with increasing DWH impacts is apparent in the relationship between N:C and distance from the DWH wellhead (Fig. 2a). A dramatic response of increasing $\mathrm{N}: \mathrm{C}$ is seen at stations near the wellhead (Fig. 2a). However, with increasing distance from the wellhead, N:C remained relatively constant. By comparison, N:C averaged across 5 replicates from 51 stations sampled as part of the Deep Gulf of Mexico Benthos program (DGoMB) was both low and relatively constant over a depth range of 200-3600 m (Fig. 2b). DGoMB stations spanned the entire deep northern Gulf of Mexico (Baguley et al. 2006a).

Meiofauna community structure was significantly dissimilar across the 4 zones (ANOSIM global test, $\mathrm{p}<0.001$ ). Most heavily impacted stations in Zone 1 were within $1 \mathrm{~km}$ of the wellhead and grouped distinctly from other impact zones in the MDS ordination (Fig. 3). Zone 2 stations clustered tightly together, but more closely to stations in Zones 3 and 4. Pairwise ANOSIM tests revealed that Zones 1 and 2 had significantly different community structure from each other and from Zones 3 and 4 (Table 3). Greater variability was observed in the ordination of stations in Zone 4, and pairwise ANOSIM suggested that community structure in Zone 4 was not signifi-

Table 2. Meiofauna community response: average abundance, evenness (Pielou's $J^{\prime}$ ), diversity (Hill's N1), and the nematode to copepod ratio $(\mathrm{N}: \mathrm{C})$ in the 4 impact zones. Percent change is defined relative to background conditions

\begin{tabular}{|lcccccccc|}
\hline Zone & $\begin{array}{c}\text { Abundance } \\
\left.\text { (ind. } 10 \mathrm{~cm}^{-2}\right)\end{array}$ & $\begin{array}{c}\text { Change } \\
(\%)\end{array}$ & $\begin{array}{c}\text { Pielou's } \\
J^{\prime}\end{array}$ & $\begin{array}{c}\text { Change } \\
(\%)\end{array}$ & N1 & $\begin{array}{c}\text { Change } \\
(\%)\end{array}$ & $\begin{array}{c}\text { N:C } \\
(\%)\end{array}$ \\
\hline 1 & 3474.1 & 181.4 & 0.091 & -75.3 & 1.17 & -48.5 & 72.4 \\
2 & 3661.0 & 196.5 & 0.187 & -49.1 & 1.53 & -32.6 & 25.5 & 220 \\
3 & 2519.9 & 104.1 & 0.273 & -25.7 & 1.84 & -18.9 & 14.6 & 83 \\
4 & 1234.6 & & 0.367 & & 2.27 & & 8.0 \\
\hline
\end{tabular}


cantly different from that of Zone $3(\mathrm{p}=$ 0.063). However, it is notable that the significance value of this pair-wise comparison only marginally exceeded the $5 \%$ threshold.

The SIMPER routine indicated that Zone 1 was $55.9 \%$ dissimilar to Zone 4 , with nematodes contributing to $89.3 \%$ of the dissimilarity, nauplii contributing to $5.3 \%$ of the dissimilarity, and copepods contributing to $4.1 \%$ of the dissimilarity (Table 3 ). Zone 1 was $40.8 \%$ dissimilar to Zone 3, with nematodes contributing to $87.3 \%$ of the dissimilarity, nauplii contributing to $6.2 \%$ of the dissimilarity, and copepods contributing to $4.8 \%$ of the dissimilarity (Table 3 ). Zone 2 was $30.6 \%$ dissimilar to Zone 1, with nematodes contributing to $87.3 \%$ of the dissimilarity, nauplii con-
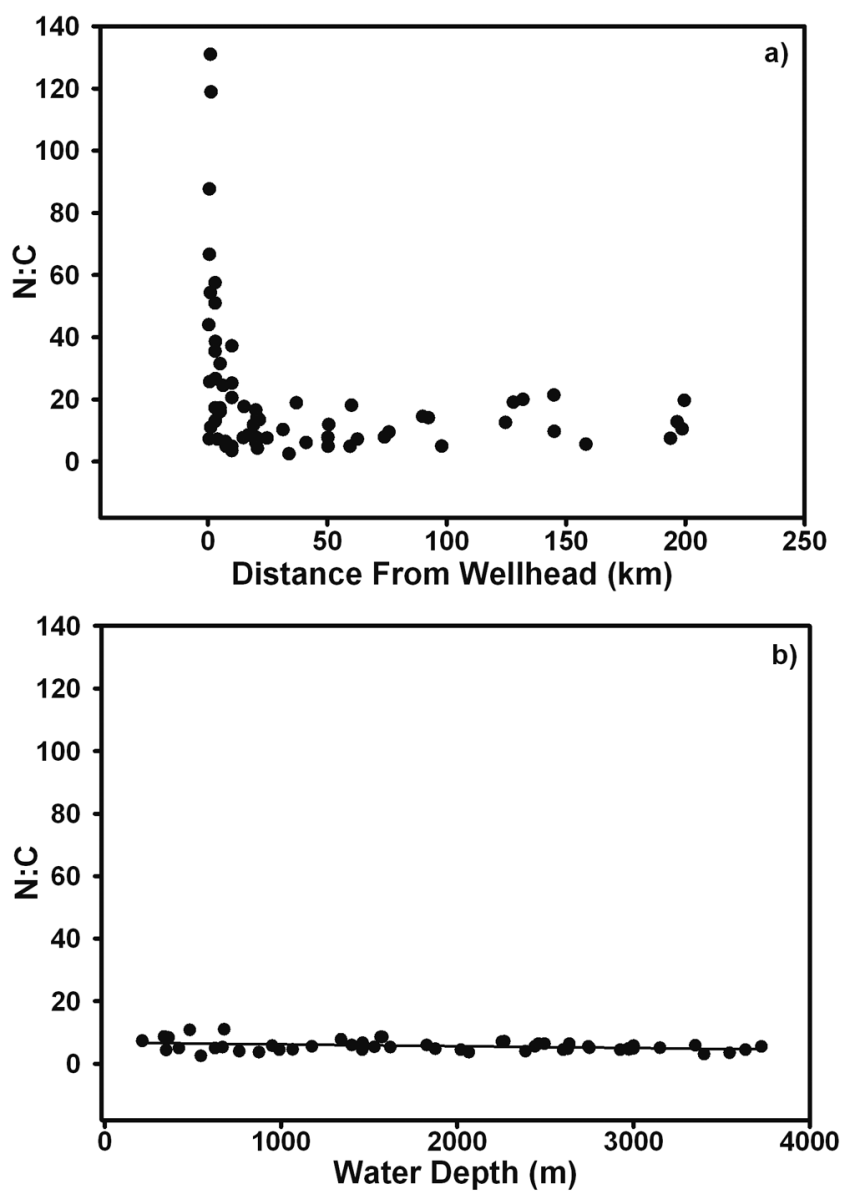

Fig. 2. Nematode to copepod ratio (N:C) (a) with respect to distance from the Deepwater Horizon (DWH) wellhead at 66 DWH priority stations, and (b) at 51 stations sampled during the Deep Gulf of Mexico Benthos (DGoMB) program (2000-2003). N:C at the DGoMB station is the average of 5 replicate samples per station
Table 3. Results of the pairwise 1-way ANOSIM test of zone differences, and SIMPER results indicating taxa-specific percentage contributions to the pairwise dissimilarities

\begin{tabular}{|lcccccc|}
\hline \multirow{2}{*}{$\begin{array}{l}\text { Zone } \\
(\%)\end{array}$} & Zone & $\begin{array}{c}\mathrm{p} \\
(\%)\end{array}$ & $\begin{array}{c}\text { Dissimilarity } \\
(\%)\end{array}$ & \multicolumn{3}{c|}{ Taxa contributing to difference } \\
Nematoda & Nauplii & Copepoda \\
\hline 1 & 2 & 0.1 & 30.6 & 87.3 & 6.1 & 4.8 \\
1 & 3 & 0.1 & 40.7 & 87.3 & 6.2 & 4.8 \\
1 & 4 & 0.1 & 55.9 & 89.3 & 5.3 & 4.1 \\
2 & 3 & 0.2 & 35.6 & 89.4 & 4.8 & 3.7 \\
2 & 4 & 0.7 & 54.9 & 90.5 & 4.4 & 3.5 \\
3 & 4 & 6.3 & 47.7 & 82.6 & 8.2 & 6.8 \\
\hline
\end{tabular}

tributing to $6.1 \%$ of the dissimilarity, and copepods contributing to $4.8 \%$ of the dissimilarity (Table 3 ). While ANOSIM weakly suggested no significant difference between Zones 3 and 4, these zones were still $47.7 \%$ dissimilar, with nematodes contributing to $82.6 \%$ of the dissimilarity, nauplii contributing to $8.2 \%$ of the dissimilarity, and copepods contributing to $6.8 \%$ of the dissimilarity (Table 3). Conversely, Zones 3 and 2 were significantly different but only $35.6 \%$ dissimilar, with nematodes contributing to $89.4 \%$ of the dissimilarity, nauplii contributing to $4.8 \%$ of the dissimilarity, and copepods contributing to $3.7 \%$ of the dissimilarity (Table 3 ). Within-group similarities determined by SIMPER were as follows: Zone 1 (63.2\%), Zone 2 (75.2\%), Zone 3 (59.6\%), and Zone $4(62.6 \%)$.

The proportional contribution of the major taxa to community structure in each zone further emphasizes the shift toward dominance by nematodes with increasing impacts (Table 4). In Zone 4, nematodes accounted for $78 \%$ of the meiofauna community, but in Zones 1-3 nematodes accounted for a greater percentage of total abundance. In Zone 1, where impacts were greatest, nematodes accounted

Table 4. Percent contribution of each meiofaunal taxon to the community structure of each zone

\begin{tabular}{|lrrrr|}
\hline Taxa & Zone 1 & Zone 2 & Zone 3 & Zone 4 \\
\hline Nematoda & 97.62 & 91.17 & 84.55 & 77.99 \\
Copepoda & 1.61 & 4.27 & 6.59 & 10.15 \\
Nauplii & 0.49 & 3.76 & 7.09 & 9.72 \\
Polychaeta & 0.27 & 0.61 & 1.08 & 1.31 \\
Ostracoda & 0.00 & 0.06 & 0.28 & 0.44 \\
Kinorhyncha & 0.00 & 0.04 & 0.30 & 0.24 \\
Bivalvia & 0.01 & 0.08 & 0.08 & 0.08 \\
Tanaidacea & 0.00 & 0.00 & 0.01 & 0.03 \\
Tardigrada & 0.00 & 0.01 & 0.01 & 0.02 \\
Aplacophora & 0.00 & 0.00 & 0.01 & 0.00 \\
Gastrotricha & 0.00 & 0.00 & 0.01 & 0.00 \\
\hline
\end{tabular}




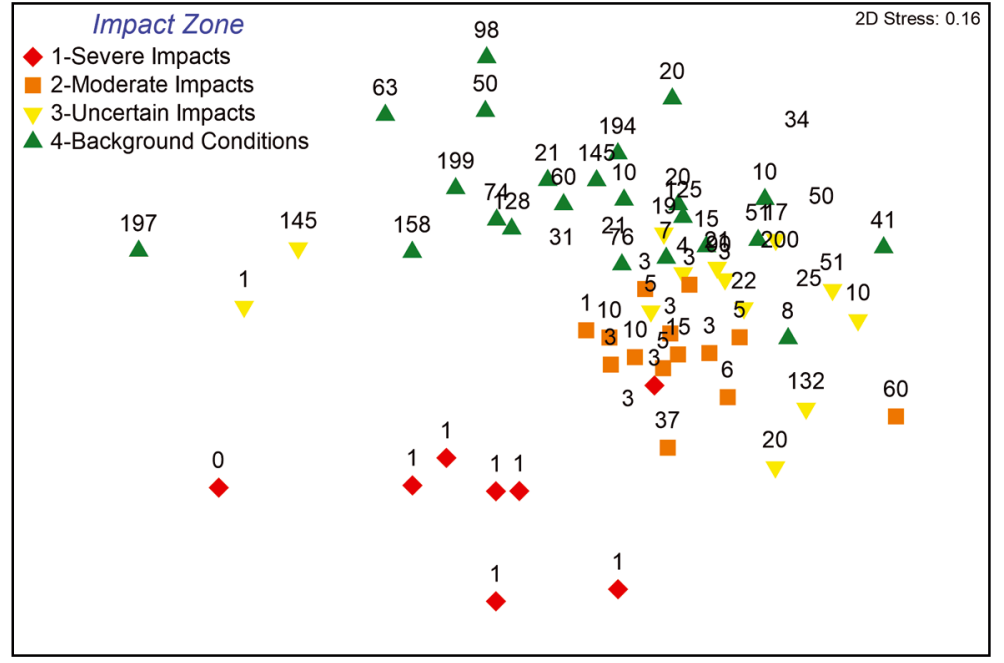

Fig. 3. Non-metric multidimensional scaling ordination of station similarities (Bray-Curtis). Symbols are impact zones and labels are distances $(\mathrm{km})$ to the Deepwater Horizon wellhead
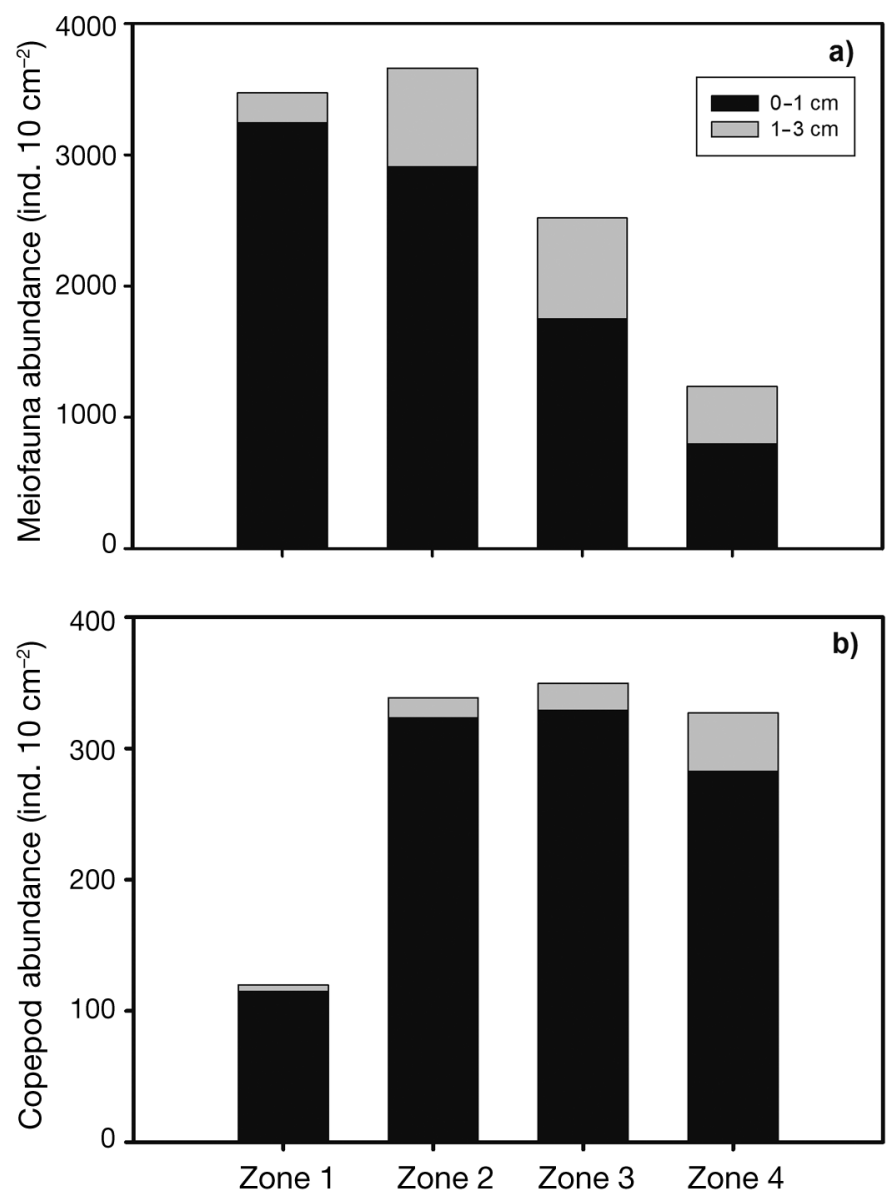

Fig. 4. (a) Total meiofauna abundance and (b) copepod abundance by zone and vertical sediment fraction. Nematode abundance mirrored that of the total meiofauna community for nearly $98 \%$ of the total abundance. Conversely, copepods and copepod nauplii accounted for roughly $20 \%$ of the total community abundance in Zone 4, but accounted for only about $2 \%$ of community abundance in Zone 1 . This constitutes a 10-fold reduction in proportional contribution to the community where impacts were most severe. Polychaete worms, ostracods, and kinorhynchs also responded negatively to increasing DWH impacts, with the lowest proportional contributions to community abundance in Zone 1.

As would be expected in muddy deepsea sediments, a greater number of total meiofauna were found in the $0-1 \mathrm{~cm}$ vertical sediment fraction compared to the 1-3 cm vertical sediment fraction (Fig. 4a). This pattern was even stronger for copepods (Fig. 4b). Two-way ANOVA to test for the interaction between impact zone and vertical distribution of total meiofauna and copepods was significant for both $(\mathrm{p}<0.0001$ and $\mathrm{p}=0.0026$, respectively), suggesting that total meiofauna and, specifically, copepod vertical distribution in sediments differs between the impact zones. The percent of total individuals and copepods found in the $0-1 \mathrm{~cm}$ vertical fraction was greatest in Zone 1. Therefore, where impacts were most severe, animals were more concentrated in the top $1 \mathrm{~cm}$ of sediment.

Spatial analysis of N:C (Fig. 4) and N1 (Fig. 5) at 66 total priority stations delineated deviations from background conditions in the vicinity of the DWH wellhead. Greater spatial variability was observed in the N1 pattern, with some areas of lower community diversity in shallower depths and to the west in the Mississippi Canyon (Fig. 5). However, the lowest diversity was observed near the DWH wellhead and along a northeast to southwest trajectory. In total, $458.4 \mathrm{~km}^{2}$ of seafloor was categorized by N1 $\leq 1.6$ in the combined red and orange polygons (Fig. 5). N:C deviations from background conditions coincide more closely with the location of the MC252 wellhead and the DWH benthic footprint identified by Montagna et al. (2013). Background measurements of $\mathrm{N}$ : C in this study and in the DGoMB study are consistently less than 20. Here, the spatial interpolation of $\mathrm{N}$ :C suggests an area of $309.7 \mathrm{~km}^{2}$ where $\mathrm{N}$ :C is greater than 21.5 (Fig. 6), a 79.6\% larger area than the $172 \mathrm{~km}^{2}$ footprint of strong and moderate impacts reported by Montagna et al. (2013). 


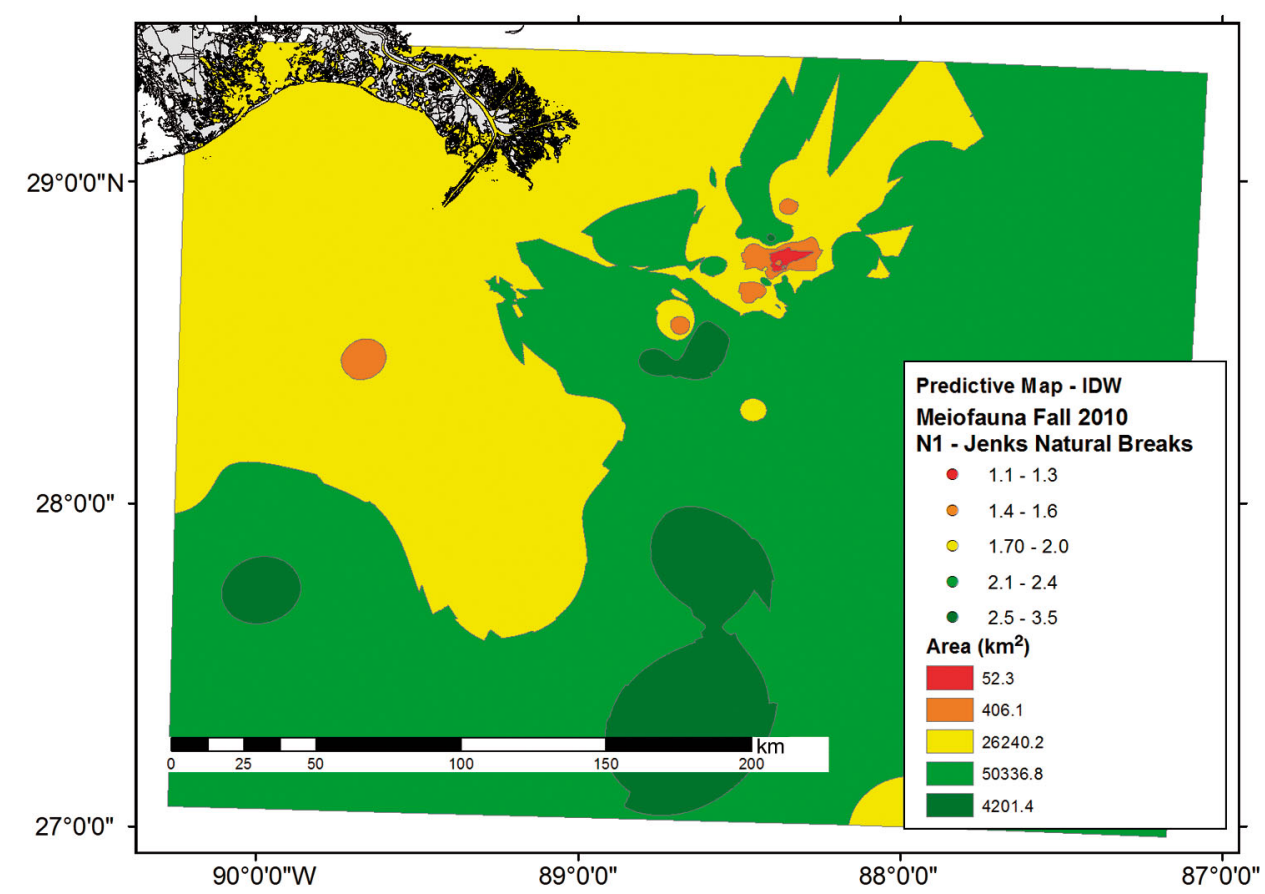

Fig. 5. GIS spatial interpolation of Hill's N1 at 66 priority stations. IDW: inverse distance weighting

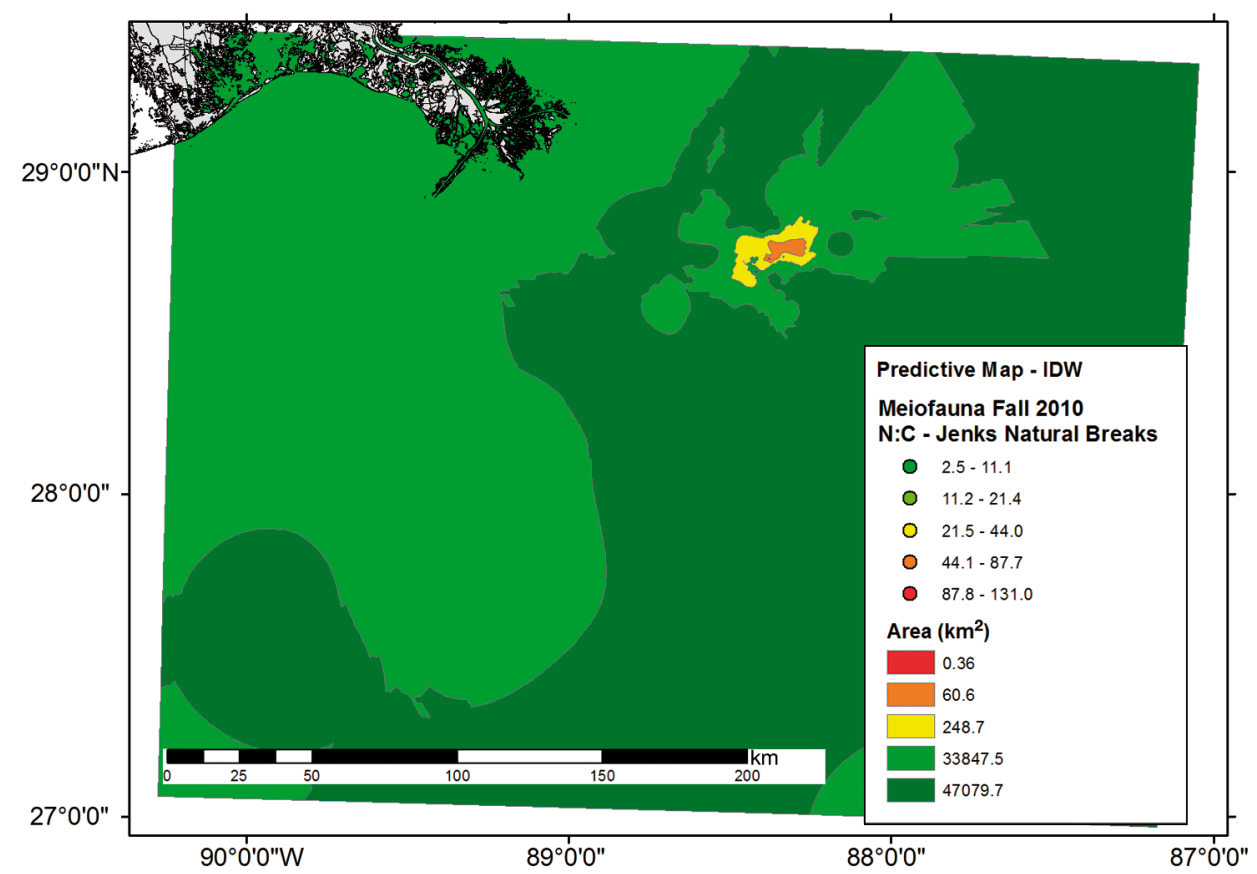

Fig. 6. GIS spatial interpolation of the nematode to copepod ratio $(\mathrm{N}: \mathrm{C})$ at 66 priority stations. IDW: inverse distance weighting

\section{DISCUSSION}

The vast majority of historic marine oil spills have occurred in relatively shallow water. These have included tanker groundings (e.g. Exxon Valdez and Amoco Cadiz), collisions (Venpet/Venoil), and wellhead blowouts (Ixtoc). There have also been tanker sinking events (e.g. the Prestige) where oil was released at the surface and continued to be released in the deep sea. However, the DWH blowout and resulting oil spill at the MC252 wellhead was unique in that it occurred in deep water (1525 m), oil and gas were exiting the wellhead together at high pressures, and chemical dispersants were applied in situ to 
emulsify oil and lessen surface impacts. It is well established that oil and natural gas being released at high pressures in combination with chemical dispersants resulted in a substantial subsurface oil and gas plume (Peterson et al. 2012). The initial blowout event also resulted in fallout of oil-laden drilling muds in the vicinity of the MC252 wellhead. Despite the deep-water origin, a documented deep-water oil plume, and known oil/mud fallout, the vast majority of funding and research associated with impacts has been focused on shallow-water or water-column processes (Peterson et al. 2012).

The DWH blowout and oil spill did affect deep-sea soft-sediment benthic meiofauna and macrofauna communities (Montagna et al. 2013). The deep-sea benthic footprint identified by Montagna et al. (2013) was generated with a combined biological/chemical PCA, where biological metrics were used in combination with chemical contaminant loads to define a single multivariate index. Here, the impact zones defined by Montagna et al. (2013) were used as treatments to test and describe the details of the deep-sea meiofauna community response to this pollution event.

The utility of meiobenthos as bioindicators of community structure and integrity in pollution studies has long been recognized (McIntyre 1977, Giere 1979, Boucher 1980), yet meiofauna have rarely been a component of oil-spill impact assessments (Lee \& Page 1997). Nematodes and harpacticoid copepods, the 2 dominant meiofauna taxa, have been particularly useful as bioindicators at population (Platt et al. 1984, Stacey \& Marcotte 1987, Coull \& Chandler 1992, Somerfield \& Clarke 1995, Schratzberger \& Warwick 1998, Bejarano et al. 2006, Höss et al. 2011, Moreno et al. 2011, Bevilacqua et al. 2012) and community levels (Wormald 1976, Fricke et al. 1981, Fleeger \& Chandler 1983, Danovaro et al. 1995). However, attaining a high level of taxonomic resolution with these or other meiofaunal taxa can be a laborious task. Alternatively, using higher taxonomic levels (i.e. order or higher) in diversity studies is significantly faster and has been shown to yield results similar to those using species-level diversity (Montagna \& Harper 1996).

In the present study, meiofauna abundance and major taxonomic diversity varied inversely with respect to each other and increasing DWH impacts. Background conditions were characterized by lower abundance and higher diversity, while impacted areas had higher abundance and lower diversity. This community response indicates that the DWH deep-sea impacts represent a balance between enrichment and toxicity, a phenomenon that is consistent with prior investigations of drilling-related activities (Montagna \& Harper 1996) and oil spill effects (Giere 1979). A similar enrichment response following the DWH spill was documented in soft-sediment meiobenthic communities that were sampled near deep-water corals (Fisher et al. 2014), and in reasonably close proximity to the stations sampled as part of the present study. The data presented by Fisher et al. (2014) corroborate the broader spatial pattern of enrichment presented here. Multiple pathways exist by which oil-derived carbon could have entered deep-sea food webs (Montagna et al. 2013), but the recently published 'fallout plume' hypothesis (Valentine et al. 2014) suggests higher fluxes of oiled bacterial flocculants to the seafloor over the spatial extent of the present study. The fallout plume may have been fueled by Colwellia (Bælum et al. 2012) or other endogenous bacterial flocculation. Therefore, elevated meiofauna abundances (particularly nematodes) at impacted stations could be evidence of a spill-related trophic response to bacterial or other labile organic constituents of the DWH 'fallout plume'.

It is also possible that indirect effects associated with this pollution event interacted to re-structure the meiofauna community (Fleeger et al. 2003). Potential indirect effects that could alter community structure include bottom-up, top-down, or competitive interactions. If predation rates are altered or if there is increased or decreased susceptibility to predation, top-down community regulation could be enhanced or alleviated (Fleeger et al. 2003). Increased food supply can have bottom-up effects that may favor more competitive consumers (Fleeger et al. 2003). Increased nematode abundance in Zones 1-3 could have resulted from a bottom-up trophic response and a competitive advantage over other meiofaunal taxa, but this community dominance shift may have also resulted from reduced predation pressure by macrobenthos.

Regardless of the ultimate cause, nematode dominance increased dramatically relative to other taxa at impacted stations. The resulting increase in $\mathrm{N}$ : C was one of the strongest indicators of DWH oil spill effects (Montagna et al. 2013), and a significant deviation from background and historic community structure in the northern Gulf of Mexico deep sea (Fig. 2). Raffaelli \& Mason (1981) proposed using a ratio of nematodes to copepods to reduce the taxonomic expertise required for assessing effects of organic enrichment on benthic communities. This metric is based on the assumption 
that as organic enrichment or toxicity increases, the $\mathrm{N}: \mathrm{C}$ increases due to the reduction of copepod abundance and/or an increase in nematode abundance.

Following the introduction of N:C by Raffaelli \& Mason (1981), several deficiencies in using this index were revealed. Many complex ecological interactions structuring benthic communities (e.g. variation in food supply and predation pressure) can bias the index on a temporal scale (Coull et al. 1981, Lambshead 1984). N:C has not always been useful in assessing oil spill effects in shallow-water systems, where it can be confounded with seasonality (e.g. Ansari \& Ingole 2002). While natural seasonal pulses of surface-derived primary production could elevate nematode dominance in deep-sea meiobenthic communities, it is unlikely that seasonality enhanced $\mathrm{N}$ :C in the region of the MC252 wellhead relative to more distant stations at the same depth and in the same general region of the Gulf of Mexico.

Variation in sediment grain size and composition can also result in different species assemblages for a given area, falsely identifying organic enrichment effects (Warwick 1981, Shiells \& Anderson 1985, Rubal et al. 2009). Additionally, Warwick (1981) asserted that sediment granulometry affects the metabolic requirements of nematodes and copepods differently, erroneously influencing the observed ratio. $\mathrm{N}: \mathrm{C}$ has not been useful in assessing oil spills on sandy beaches where sediment conditions varied between sites, and generally favored harpacticoid life histories over nematodes (e.g. Veiga et al. 2010). However, sediment granulometry is nearly constant at all stations investigated in the present study, with $>90 \%$ silt/clay, and therefore granulometry is not likely to have an effect on $\mathrm{N}: \mathrm{C}$ here.

Despite the limitations of $\mathrm{N}: \mathrm{C}$, its potential value as a tool for biomonitoring pollution events has been recognized in field and mesocosm studies (Marcotte \& Coull 1974, Fricke et al. 1981, Amjad \& Gray 1983, Gee et al. 1985, Sandulli \& Giudici 1989, Kennicutt et al. 1996, Sutherland et al. 2007, Wang et al. 2011, Riera et al. 2012). More recently, and arguably more relevant to the present study, the $\mathrm{N}$ : $\mathrm{C}$ has worked well to classify impacts of drilling activities in the Gulf of Mexico (Montagna \& Harper 1996). Given the nature of the $\mathrm{N}: \mathrm{C}$ pattern relative to distance from the DWH wellhead (Fig. 2a), the utilization of the $\mathrm{N}: \mathrm{C}$ in this study is more than just an informative parameter in assessing community response. It may be one of the strongest community-related metrics of DWH impacts until finer-level taxonomic assessments can be completed.
Despite interactions with sediment properties, seasonality, or various other environmental conditions, meiobenthic copepods have been useful indicators of oil pollution or drilling-related impacts (Giere 1979, Fricke et al. 1981, Elmgren et al. 1983, Montagna \& Harper 1996, Ansari \& Ingole 2002). Studies of PAH toxicity on harpacticoid copepods have revealed negative effects on reproductive output (Bejarano et al. 2006) and development (Bang et al. 2009). While high doses of environmental contaminants can be acutely lethal, toxic effects of crude oil and its constituents may be sublethal at low or moderate doses (Bejarano et al. 2006). Sublethal effects may still have cascading negative effects on copepod populations if major reproductive endpoints are not realized (Bejarano et al. 2006). In the present study, copepod and nauplii abundances were significantly reduced where impacts were greatest, suggesting acute DWH-related toxicity in Zone 1, where PAH concentrations ranged from 1162 to $47559 \mathrm{ppb}$ (Table 1). In Zone 2, where impacts were moderate and PAH concentrations ranged from 370 to $2436 \mathrm{ppb}$ (Table 1), copepod abundance was not different from that under background conditions, but nauplii abundance was lower. Lower nauplii abundances may be due to reduced fertilization success or successful metamorphosis from nauplius to copepodite (Bejarano et al. 2006). While simple measures of abundance may not suggest acute toxicity to copepods at intermediate impact levels or where impacts were uncertain, it is possible that more refined taxonomic investigations could delineate biodiversity impacts and shifts in copepod community structure at these stations.

Abundances of minor taxa were much lower than those of nematodes or copepods. Where impacts were most severe, the total number of taxa was clearly reduced. Kinorhynchs, polychaetes, and ostracods all had lowest abundances in Zone 1, suggesting toxic effects, and ostracods and kinorhynchs had no contribution to abundance in this zone (Table 4). Interestingly, abundances of kinorhynchs and polychaetes increased in Zones 2 and 3 relative to background conditions. This response may further suggest greater enrichment effects and an associated trophic response where toxic impacts were moderate or uncertain, similar to the patterns of second-order responders described in the classic Pearson \& Rosenberg (1978) conceptual model of benthic responses to organic enrichment. Ostracod abundance was similar in Zones 3 and 4, but reduced in Zones 1 and 2. Overall taxonomic abundance patterns suggest that meiobenthic crustaceans (cope- 
pods and ostracods) may be relatively more sensitive than non-crustacean taxa.

In summary, the spatial analysis of N1 and N:C at 66 total stations indicates that the benthic footprint may be larger than previously reported by Montagna et al. (2013). While the N1 pattern was more heterogeneous, the $\mathrm{N}: \mathrm{C}$ pattern did resemble the benthic footprint of Montagna et al. (2013). This is not surprising because N:C loaded strongly on PC1 of Montagna et al. (2013) and strongly contributes to identifying the previously reported benthic footprint. Here, spatial analysis of N:C at a greater number of stations indicates a potential $80 \%$ increase in area of impacted seafloor. Adding stations to GIS analyses increases resolution and fills data gaps that limit geospatial models. As additional data become available from the 102 non-priority stations sampled during the 2010 response cruises, a more complete understanding of the spatial extent of the DWH benthic footprint and associated impacts on the meiobenthic community will be developed. Furthermore, additional taxonomic resolution should also shed light on more subtle impacts that are not observed by investigating major taxa.

Acknowledgements. Sample collection occurred during cruises on board the RVs 'Gyre' and 'Ocean Veritas' during the Deepwater Horizon OSAT Response. We thank the captains and crews of both vessels for their assistance with field sampling. Funding for this research was provided by the NOAA Natural Resource Damage Assessment. The views expressed herein are those of the authors and do not necessarily reflect the views of NOAA.

\section{LITERATURE CITED}

Amjad S, Gray JS (1983) Use of the nematode-copepod ratio as an index of organic pollution. Mar Pollut Bull 14: 178-181

Ansari ZA, Ingole B (2002) Effect of an oil spill from MV Sea Transporter on intertidal meiofauna at Goa, India. Mar Pollut Bull 44:396-402

Bælum J, Borglin S, Chakraborty R, Fortney JL and others (2012) Deep-sea bacteria enriched by oil and dispersant from the Deepwater Horizon spill. Environ Microbiol 14: 2405-2416

Baguley JG, Montagna PA, Hyde LJ, Kalke RD, Rowe GT (2006a) Metazoan meiofauna abundance in relation to environmental variables in the Northern Gulf of Mexico deep sea. Deep-Sea Res I 53:1344-1362

Baguley JG, Montagna PA, Lee W, Hyde LJ, Rowe GT (2006b) Spatial and bathymetric trends in Harpacticoida (Copepoda) community structure in the Northern Gulf of Mexico deep-sea. J Exp Mar Biol Ecol 330:327-341

Baguley JG, Montagna PA, Hyde LJ, Rowe GT (2008) Metazoan meiofauna biomass, grazing, and weight-dependent respiration in the Northern Gulf of Mexico deep sea. Deep-Sea Res II 55:2607-2616
Bang HW, Lee W, Kwak IS (2009) Detecting points as developmental delay based on the life-history development and urosome deformity of the harpacticoid copepod, Tigriopus japonicus sensu lato, following exposure to benzo(a)pyrene. Chemosphere 76:1435-1439

Bejarano AC, Chandler GT, Lijian H, Coull BC (2006) Individual to population level effects of South Louisiana crude oil water accommodated hydrocarbon fraction (WAF) on a marine meiobenthic copepod. J Exp Mar Biol Ecol 332:49-59

Bell SS (1980) Meiofauna-macrofauna interactions in a high saltmarsh habitat. Ecol Monogr 50:487-505

Bevilacqua S, Sandulli R, Plicanti A, Terlizzi A (2012) Taxonomic distinctness in Mediterranean marine nematodes and its relevance for environmental impact assessment. Mar Pollut Bull 64:1409-1416

Bik HM, Halanych KM, Sharma J, Thomas WK (2012) Dramatic shifts in benthic microbial eukaryote communities following the Deepwater Horizon oil spill. PLoS ONE 7: e38550

Blake JA, Grassle JF (1994) Benthic community structure on the US Atlantic slope off the Carolinas: spatial heterogeneity in a current-dominated system. Deep-Sea Res II 41:835-874

> Boucher G (1980) Impact of Amoco Cadiz oil spill on intertidal and sublittoral meiofauna. Mar Pollut Bull 11: 95-101

> Burgess R (2001) An improved protocol for separating meiofauna from sediments using colloidal silica sols. Mar Ecol Prog Ser 214:161-165

- Carman KR, Todaro MA (1996) Influence of polycyclic aromatic hydrocarbons on the meiobenthic-copepod community of a Louisiana salt marsh. J Exp Mar Biol Ecol 198:37-54

Coull BC (1972) Species diversity and faunal affinities of meiobenthic Copepoda in the deep sea. Mar Biol 14: 48-51

Coull BC, Chandler GT (1992) Pollution and meiofauna: field, laboratory, and mesocosm studies. Oceanogr Mar Biol Annu Rev 30:191-271

> Coull BC, Hicks GRF, Wells BJ (1981) Nematode/copepod ratios or monitoring pollution: a rebuttal. Mar Pollut Bull 12:378-381

Danovaro R, Fabiano M, Vincx M (1995) Meiofauna response to the Agip Abruzzo oil spill in subtidal sediments of the Ligurian Sea. Mar Pollut Bull 30:133-145

Danovaro R, Gambi C, Anno AD, Corinaldesi C and others (2008) Exponential decline of deep-sea ecosystem functioning linked to benthic biodiversity loss. Curr Biol 18: $1-8$

deJonge VN, Bouwman LA (1977) A simple density separation technique for quantitative isolation of meiobenthos using the colloidal silica Ludox-TM. Mar Biol 42:143-148

Elmgren R, Sansson S, Larsson U, Sundelin B, Boehm PD (1983) The "Tsesis" oil spill: acute and long-term impact on the benthos. Mar Biol 73:51-65

Fisher CR, Demopoulos AWJ, Cordes EE, Baums IB, White HK, Bourque JR (2014) Coral communities as indicators of ecosystem-level impacts of the Deepwater Horizon spill. BioScience 64:796-807

> Fleeger JW, Chandler GT (1983) Meiofauna reponses to an experimental oil spill in a Louisiana salt marsh. Mar Ecol Prog Ser 11:257-264

> Fleeger JW, Carman KR, Nisbet RM (2003) Indirect effects of contaminants in aquatic ecosystems. Sci Total Environ 
$317: 207-233$

Fricke AH, Hennig HFKO, Orren MJ (1981) Relationship between oil pollution and psammolittoral meiofauna density of two South African beaches. Mar Environ Res 5: 59-77

Gage JD (1979) Macrobenthic community structure in the Rockall Trough. Ambio Spec Rep 6:43-46

Gage JD (2003) Food inputs, utilization, carbon flow, and energetics. In: Tyler PA (ed) Ecosystems of the deep. Elsevier Science BV, Amsterdam, p 313-380

Gee MJ, Warwick RM, Schaanning M, Berge JA, Ambrose WG (1985) Effects of organic enrichment on meiofaunal abundance and community structure in sublittoral soft sediments. J Exp Mar Biol Ecol 91:247-262

Giere O (1979) The impact of oil pollution on intertidal meiofauna. Field studies after the La Coruna spill, May 1976. Cah Biol Mar 20:231-251

Giere O (2009) Meiobenthology: the microscopic motile fauna of aquatic sediments. Springer-Verlag, Berlin

Grassle JF, Maciolek NJ (1992) Deep-sea species richness: regional and local diversity estimates from quantitative bottom samples. Am Nat 139:313-341

> Grassle JF, Morse-Porteous L (1987) Macrofaunal colonization of disturbed deep-sea environments and the structure of deep-sea benthic communities. Deep-Sea Res 34: 1911-1950

Gray JS (1981) The ecology of marine sediments. Cambridge University Press, Cambridge

Haedrich RL, Devine J, Kendal V (2008) Predictors of species richness in the deep-benthic fauna of the northern Gulf of Mexico. Deep-Sea Res II 55:2650-2656

Hecker B, Paul AZ (1979) Abyssal community structure of the benthic infauna of the eastern equatorial Pacific: DOMES sites A, B, and C. In: Bischoff JF, Piper DZ (eds) Marine geology and oceanography of the Pacific Manganese Nodule Province. Mar Sci 9, Plenum Press, New York, NY, p 287-308

Hessler RR, Sanders HL (1967) Faunal diversity in the deep sea. Deep-Sea Res 14:65-78

> Höss S, Claus E, Von der Ohe PC, Brinke M, Güde H, Heininger P, Traunspurger W (2011) Nematode species at risk: a metric to assess pollution in soft sediments of freshwaters. Environ Int 37:940-949

Jenks GF (1967) The data model concept in statistical mapping. Int Yearbook Cartogr 7:186-190

Jumars PA (1976) Deep-sea species diversity: does it have a characteristic scale? J Mar Res 34:217-246

Kennicutt MC II, Green RH, Montagna PA, Roscigno PF (1996) Gulf of Mexico Offshore Operations Experiment (GOOMEX). Phase I. Sublethal responses to contaminant exposure-introduction and overview. Can J Fish Aquat Sci 53:2540-2553

Kessler JD, Valentine DL, Redmond MC, Du M and others (2011) A persistent oxygen anomaly reveals the fate of spilled methane in the deep Gulf of Mexico. Science 331: 312-315

Kostka JE, Prakash O, Overholt WA, Green SJ, Freyer G, Canion A, Delgardio J (2011) Hydrocarbon-degrading bacteria and the bacterial community response in Gulf of Mexico beach sands impacted by the Deepwater Horizon oil spill. Appl Environ Microbiol 77:7962-7974

Lambshead PJD (1984) The nematode/copepod ratio-some anomalous results from the Firth of Clyde. Mar Pollut Bull 15:256-259

Lee RF, Page DS (1997) Petroleum hydrocarbons and their effects in subtidal regions after major oil spills. Mar Pollut Bull 34:928-940

Lindgren JF, Hassellöv IM, Dahllöf I (2012) Meiofaunal and bacterial community response to diesel additions in a microcosm study. Mar Pollut Bull 64:595-601

Lu Z, Deng Y, Van Nostrand JD, He Z, Voordeckers J, Zhou A, Lee Y (2012) Microbial gene functions enriched in the Deepwater Horizon deep-sea oil plume. ISME J 6: 451-460

Lubchenco J, McNutt M, Lehr B, Sogge M, Miller M, Hammond S, Conner W (2010) BP Deepwater Horizon oil budget: what happened to the oil? NOAA/USGS Federal Science Report. Available at: www.noaanews.noaa.gov/ stories2010/PDFs/OilBudget_description_\%2083final. pdf (accessed 15 Jan 2015)

Mahaut ML, Sibuet M, Shirayama Y (1995) Weight-dependent respiration rates in deep-sea organisms. Deep-Sea Res 42:1575-1582

Marcotte BM, Coull BC (1974) Pollution, diversity and meiobenthic communities in the North Adriatic (Bay of Piran, Yugoslavia). Vie Milieu 24:281-300

> Mason OU, Hazen TC, Borglin S, Chain PG, Dubinsky EA, Fortney JL, Han J (2012) Metagenome, metatranscriptome and single-cell sequencing reveal microbial response to Deepwater Horizon oil spill. ISME J 6: 1715-1727

McCall BD, Pennings SC (2012) Disturbance and recovery of salt marsh arthropod communities following BP Deepwater Horizon oil spill. PLoS ONE 7:e32735

McIntyre AD (1977) Effects of pollution on meiofauna populations on inshore benthos. In: Coull BC (ed) Ecology of marine benthos. University of South Carolina Press, Columbia, SC, p 301-318

Montagna P, Harper DE Jr (1996) Benthic infaunal longterm response to offshore production platforms in the Gulf of Mexico. Can J Fish Aquat Sci 53:2567-2588

> Montagna PA, Baguley JG, Cooksey C, Hartwell I and others (2013) Deep-sea benthic footprint of the Deepwater Horizon blowout. PLoS ONE 8:e70540

Moreno M, Semprucci F, Vezzulli L, Balsamo M, Fabiano M, Albertelli G (2011) The use of nematodes in assessing ecological quality status in the Mediterranean coastal ecosystems. Ecol Indic 11:328-336

Neff JM, Rabalais NN, Boesch DF (1987) Offshore oil and gas development activities potentially causing long-term environmental effects. In: Boesch DF, Rabalais NN (eds) Long-term environmental effects of offshore oil and gas development. Elsevier Applied Science, London, p 149-174

Neff JM, Stout SA, Gunster DG (2005) Ecological risk assessment of polycyclic aromatic hydrocarbons in sediments: identifying sources and ecological hazards. Integr Environ Assess Manag 1:22-33

NRDA (Natural Resource Damage Assessment) (2011) Study plan for NRDA-Phase II Project: deepwater sediment sampling to assess post-spill benthic impacts from the Deepwater Horizon oil spill. Deepwater Benthic Communities Technical Working Group. Available at: www.doi.gov/deepwaterhorizon/adminrecord/upload/ DeepBenthicSedimentSampling_5-20-2011-allsignedredacted.pdf (accessed 15 Jan 2015)

Pearson TH, Rosenberg R (1978) Macrobenthic succession in relation to organic enrichment and pollution of the marine environment. Oceanogr Mar Biol Annu Rev 16: 229-311 
Peterson $\mathrm{CH}$, Anderson SS, Cherr GN, Ambrose RF and others (2012) A tale of two spills: novel science and policy implications of an emerging new oil spill model. BioScience 62:461-469

Platt HM, Shaw KM, Lambshead PJD (1984) Nematode species abundance patterns and their use in the detection of environmental perturbations. Hydrobiologia 118:59-66

Raffaelli DG, Mason CF (1981) Pollution monitoring with meiofauna, using the ratio of nematodes to copepods. Mar Pollut Bull 12:158-163

Rex MA (1981) Community structure in the deep-sea benthos. Annu Rev Ecol Syst 12:331-353

Riera R, Sanchez-Jerez P, Rodriguez M, Ramos E (2012) Long-term monitoring of fish farms: application of nematode/copepod index to oligotrophic conditions. Mar Pollut Bull 64:844-850

Rowe GT, Kennicutt MC II (eds) (2009) Northern Gulf of Mexico continental slope habitats and benthic ecology study: Final report. OCS Study MMS 2009-039. US Department of the Interior, Minerals Management Service, Gulf of Mexico OCS Region, New Orleans, LA

Rowe GT, Polloni PT, Haedrich RL (1982) The deep-sea macrobenthos on the continental margin of the northwest Atlantic Ocean. Deep-Sea Res 29:257-278

Rubal M, Veiga P, Besteiro C (2009) Nematode/copepod index: importance of sedimentary parameters, sampling methodology and baseline values. Thalassas 25:9-18

> Ryerson TB, Camilli R, Kessler JD, Kujawinski EB and others (2012) Chemical data quantify Deepwater Horizon hydrocarbon flow rate and environmental distribution. Proc Natl Acad Sci USA 109:20246-20253

Sandulli R, Giudici MN (1989) Effects of organic enrichment on meiofauna: a laboratory study. Mar Pollut Bull 20: 223-227

Schratzberger M, Warwick RM (1998) Effects of the intensity and frequency of organic enrichment on two estuarine nematode communities. Mar Ecol Prog Ser 164:83-94

Schwinghamer P (1981) Characteristic size distributions of integral benthic communities. Can J Fish Aquat Sci 38: 1255-1263

Shiells GM, Anderson KJ (1985) Pollution monitoring using the nematode/copepod ratio-a practical application. Mar Pollut Bull 16:62-68

Silliman BR, van de Koppel J, McCoy MW, Diller J, Kasozi GN, Earl K, Adams PN (2012) Degradation and resilience in Louisiana salt marshes after the BP-Deepwater Horizon oil spill. Proc Natl Acad Sci USA 109: 11234-11239

Somerfield PJ, Clarke KR (1995) Taxonomic levels, in marine community studies, revisited. Mar Ecol Prog Ser 127: 113-119

Stacey BM, Marcotte BM (1987) Chronic effect of No. 2 fuel oil on population dynamics of harpacticoid copepods in experimental marine mesocosms. Mar Ecol Prog Ser 40: 61-68

Editorial responsibility: Robert Stead, Puerto Montt, Chile
Sutherland TF, Levings CD, Petersen SA, Poon P, Piercey B (2007) The use of meiofauna as an indicator of benthic organic enrichment associated with salmonoid aquaculture. Mar Pollut Bull 54:1249-1261

Tenore KR (1977) Food chain pathways in detrital feeding benthic communities: a review, with new observations on sediment resuspension and detrital recycling. In: Coull BC (ed) Ecology of the marine benthos. University of South Carolina Press, Columbia, SC, p 37-54

Thistle D (1978) Harpacticoid dispersion patterns -implications for deep-sea diversity maintenance. J Mar Res 36: 377-397

Thistle D (2003) The deep-sea floor: an overview. In: Tyler PA (ed) Ecosystems of the deep. Elsevier Science BV, Amsterdam, p 5-38

Tyler PA (2003) Introduction. In: Tyler PA (ed) Ecosystems of the deep. Elsevier Science BV, Amsterdam, p 1-4

UAC (Unified Area Command) (2010) Deepwater Horizon MC 252 Response Unified Area Command-strategic plan for sub-sea and sub-surface oil and dispersant detection, sampling, and monitoring. November 13, 2010. Final, US Coast Guard and BP Exploration and Production, New Orleans, LA. Available at: www. restorethegulf.gov/sites/default/files/documents/pdf/13_ NOV_2010_SMU_Strategic_Plan.pdf (accessed 15 Jan 2015)

> Valentine DL, Fisher GB, Bagby SC, Nelson RK, Reddy CM, Sylva SP, Woo MA (2014) Fallout plume of submerged oil from Deepwater Horizon. Proc Natl Acad Sci USA 111: 15906-15911

> Veiga P, Besteiro C, Rubal M (2010) Meiofauna communities in exposed sandy beaches on the Galician coast (NW Spain), six months after the Prestige oil spill: the role of polycyclic aromatic hydrocarbons (PAHs). Sci Mar 74: 385-394

> Wang J, Zhou H, Zhang Z, Cong B, Xu S (2011) Effects of organic enrichment on sandy beach meiofauna: a laboratory microcosm experiment. J Ocean Univ China 10: 246-254

> Warwick RM (1981) The nematode/copepod ratio and its use in pollution ecology. Mar Pollut Bull 12:329-333

Wei CL, Rowe GT, Escobar-Briones E, Boetius A and others (2010a) Global patterns and predictions of seafloor biomass using random forests. PLoS ONE 5:e15323

- Wei CL, Rowe GT, Hubbard GF, Scheltema AH and others (2010b) Bathymetric zonation of deep-sea macrofauna in relation to export of surface phytoplankton production. Mar Ecol Prog Ser 399:1-14

White HK, Hsing PY, Cho W, Shank TM and others (2012) Impact of the Deepwater Horizon oil spill on a deepwater coral community in the Gulf of Mexico. Proc Natl Acad Sci USA 109:20303-20308

- Wormald AP (1976) Effects of a spill of marine diesel on the meiofauna of a sandy beach at Picnic Bay, Hong Kong. Environ Pollut 11:117-130

Submitted: October 22, 2014; Accepted: March 19, 2015 Proofs received from author(s): May 11, 2015 